\title{
Solar fed BLDC motor drive for mixer grinder using a buck-boost converter
}

\author{
Deekshitha S. Nayak, R. Shivarudras wamy \\ Department of Electrical and Electronics Engineering, Manipal Institute of Technology, MAHE, Manipal, India
}

\begin{tabular}{|c|c|}
\hline Article Info & ABSTRACT \\
\hline Article history: & In existing mixer grinders, the universal motor is used due to its high starting \\
\hline Received Jun 27, 2019 & torque than the induction motor. To achieve higher speed for smaller devices, \\
\hline Revised Aug 18, 2019 & $\begin{array}{l}\text { the implementation of the universal motor becomes cheaper. The absence of } \\
\text { brushes and the reduction of noise in the BLDC extends its lifetime, making }\end{array}$ \\
\hline Accepted Sep 26, 2019 & $\begin{array}{l}\text { it ideal for a mixer grinder. The solar-powered BLDC motor drive for } \\
\text { a mixer grinder is presented in this paper. A DC-DC Buck Boost (BB) }\end{array}$ \\
\hline Keywords: & $\begin{array}{l}\text { converter is utilized to operate the PV (photovoltaic) array at its highest } \\
\text { power. The proposed hysteresis current (HC) control BLDC system }\end{array}$ \\
\hline $\begin{array}{l}\text { BLDC } \\
\text { Hysteresis current control } \\
\text { MATLAB }\end{array}$ & $\begin{array}{l}\text { is developed in the MATLAB. A comparison performance is demonstrated } \\
\text { between the commercially available mixer grinder and the simulated } \\
\text { proposed system. }\end{array}$ \\
\hline
\end{tabular}

This is an open access article under the CC BY-SA license.

Mixer grinder

Solar

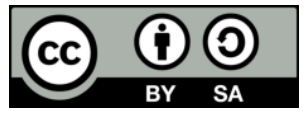

\section{Corresponding Author:}

R. Shivarudras wamy,

Department of Electrical and Electronics Engineering,

Manipal Institute of Technology,

Manipal Academy of Higher Education, Manipal, India.

Email: shivarudraswamy.r@ manipal.edu

\section{INTRODUCTION}

Energy efficient appliances are widely used due to scarce energy resources. In home appliances, the universal motor, the induction motor or brushed DC motor is used [1]. The mixer grinder is commonly used in many homes for grinding or mixing ingredients [2]. The universal motor is generally used as drive motor in the most mixer grinder. It has inherently inverse torque vs speed characteristics which suits the mixer grinder load characteristics [3-4]. When the motor is switched on, and the grinding/mixing of the ingredients takes place, the requirement of the torque reduces and the speed increases [5]. For maintaining the quality of the grinding/mixing, the speed is controlled to a set value, which in turn does not affect a quality output of the mixer grinder and also consumes less power. The brush and commutator arrangements in the universal motor can cause sparking, and electromagnetic interference can lead to lower efficiency [6-7]. So, a BLDC motor should be used in the mixer grinder because of its easy speed torque control and compact size [8-9]. As the efficiency vs torque characteristics of the BLDC motor is almost flat, the mixer operates at low speed and part load saving energy [10-11]. In this paper, the solar fed BLDC mixer grinder is designed, which has higher efficiency than the existing AC universal motor mixer grinder and for controlling the speed of the motor, hysteresis current controller is designed.

\section{PROPOSED METHOD}

Figure 1 shows the proposed outline of the BLDC motor drive used in the mixer grinder. As the efficiency of a BLDC motor is high [12], the size of the PV array is reduced as well its installation 
price. Thus, its higher power factor reduces the capacity of the used voltage source inverter (VSI). A buck-boost converter is placed amid PV array and voltage source inverter. Additionally, the buck-boost converter is operated by controlling PV array using the Perturb and Observer MPPT algorithm technique. The BLDC mixer grinder is fed by the VSI. The three current sensors and hall sensor are fed to a BLDC motor control. The BLDC motor control is the hysteresis current controller, and gate signals from a controller are fed to the VSI for controlling the speed of the motor.

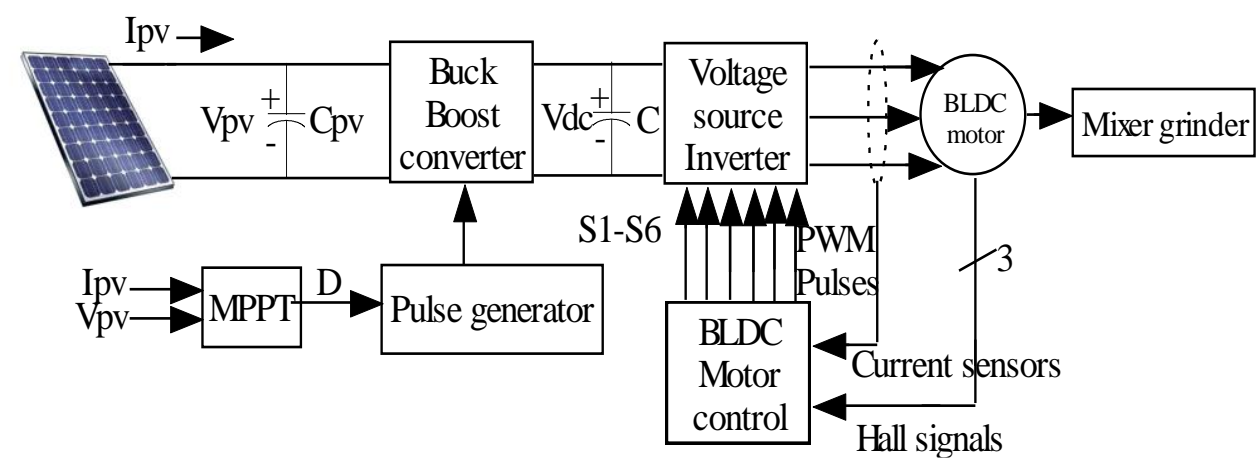

Figure 1. Schematic diagram of a proposed mixer grinder

\section{RESEARCH METHOD}

For the desired operation of the mixer grinder, suitable specifications and design of the PV array, buck-boost converter, and BLDC mixer grinder play an important role. A 4-pole BLDC motor with $10000 \mathrm{rpm}$ and $200 \mathrm{~W}$ is chosen. The PV array, Buck-Boost converter, and the mixer grinder are preferred in a manner whereby the function of the system is not disturbed under any climatic conditions.

\subsection{PV array and MPPT}

The PV array with peak power of $300 \mathrm{~W}$ was designed for a $200 \mathrm{~W}$ mixer grinder in order to compensate the motor and converter losses. Table 1 shows the design of the PV array and the MPPT technique used was the Perturb and Observer algorithm, as shown in Figure 2. This algorithm uses less measured parameters and simple feedback scheme.

Table 1. Design of PV array

\begin{tabular}{cc}
\hline PV module $($ HB-12100) & value \\
\hline $\mathrm{N}_{\mathrm{s}}$ & 36 \\
$\mathrm{~V}_{\mathrm{o}}$ & $21 \mathrm{~V}$ \\
$\mathrm{I}_{\mathrm{o}}$ & $10.1 \mathrm{~A}$ \\
$\mathrm{~V}_{\mathrm{m}}$ & $17 \mathrm{~V}$ \\
$\mathrm{I}_{\mathrm{m}}$ & $9 \mathrm{~A}$ \\
$\mathrm{~V}_{\mathrm{oc}}$ & $63 \mathrm{~V}$ \\
$\mathrm{I}_{\mathrm{sc}}$ & $7.1 \mathrm{~A}$ \\
Modules in series & 2 \\
Modules in parallel & 1 \\
Peak Power & $300 \mathrm{~W}$ \\
\hline
\end{tabular}

In this method, the voltage of the module is periodically given the perturbations, and consistent power output is compared with a prior perturbing cycle. Due to a perturbation, if power increases, then a perturbation remains in the same direction. After power peak is attained, power is zero at MPP, and next instant decreases and then, perturbations reverse. When a stable state is reached, the algorithm oscillates around a peak power point. To retain small power variations, the perturbations size is maintained very small. The method is advanced so it sets reference voltage of a module analogous to the peak voltage of the module [13]. The PI controller then acts to transfer an operating point of a module to that specific voltage level. Some power loss is detected due to this perturbation as well as failure for tracking maximum power under rapid varying climatic conditions. A MPPT algorithm functions based on a derivative of power output (P) with the voltage of panel $(\mathrm{V})$, at maximu $\mathrm{m}$ power point which is equal to zero. 


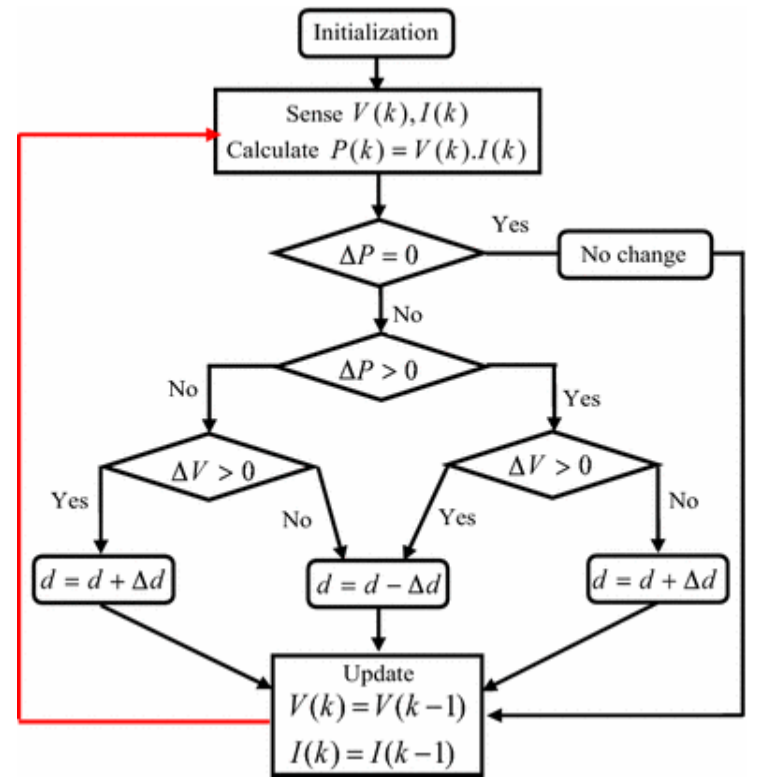

Figure 2. Flowchart of the perturb and observer algorithm

\subsection{Buck-boost converter}

The buck-boost converter is DC-DC converter with output voltage magnitude is either less than or greater than the magnitude of the input voltage. Figure 3 shows that the non-inverting BB convertergenerates an output voltage of the same polarity as the input voltage. Table 2 shows specifications of a BB converter.

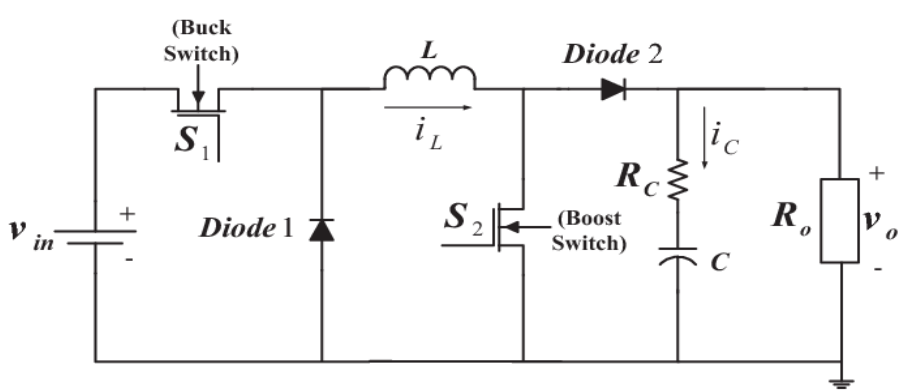

Figure 3. Circuit of a buck-boost converter

\begin{tabular}{cc}
\hline Parameter & value \\
\hline Input voltage $\left(\mathrm{V}_{\text {in }}\right)$ & $34 \mathrm{~V}$ \\
Output voltage $\left(\mathrm{V}_{\mathrm{o}}\right)$ & $48 \mathrm{~V}$ \\
Switching frequency $\left(\mathrm{f}_{\text {sw }}\right)$ & $500 \mathrm{kHz}$ \\
Inductor current ripple $\left(\mathrm{I}_{\text {ripple }}\right)$ & $30 \%$ \\
Output voltage ripple $\left(\mathrm{V}_{\text {ripple }}\right)$ & $10 \mathrm{mV}$ \\
\hline
\end{tabular}

The duty cycle is given as:

$$
D=\frac{V_{o}}{V_{o}+V_{\text {in }}}=\frac{48}{48+34}=0.58
$$

The output voltage from the BB converter is a rated DC link voltage of the VSI. By neglecting converter loss, the current through a DC link $\left(I_{d c}\right)$ is, 


$$
I_{d c}=I_{o}=\frac{P_{m p}}{V_{o}}=\frac{300}{48}=6.25 \mathrm{~A}
$$

The value of the inductor is,

$$
\mathrm{L}=\frac{D V_{p v}}{f_{s w} \Delta I_{L}}=11.95 \mu \mathrm{H}
$$

where $\Delta_{L}$ is an inductor current ripple. The value of the capacitor is,

$$
\begin{aligned}
& \omega=2 \pi \mathrm{f}=2 \pi \frac{N_{\text {rated }} P}{120}=2094.3 \mathrm{rad} / \mathrm{sec} \\
& C=\frac{I_{d c}}{6 \omega \Delta V_{d c}}=1036.2 \mu \mathrm{F}
\end{aligned}
$$

where, $\Delta V_{d c}$ is $\mathrm{V}_{\mathrm{dc}}$ to $1 \%$ [1].

Table 3 shows the switching state of the VSI. The three hall sensors are used to produce the gate signal to the VSI by electronic commutations. Electronic commutations refer to a commutation of current flows through the windings of the BLDC motor in predefined sequences by the decoder such that direct current is symmetrically drawn from a DC bus of the voltage source inverter for $120^{\circ}$ and employed in

\begin{tabular}{|c|c|c|c|c|c|c|c|c|c|}
\hline \multirow{2}{*}{ Rotor position $\theta$} & \multicolumn{3}{|c|}{ Hall signal } & \multicolumn{6}{|c|}{ Switching state } \\
\hline & $\mathrm{H}_{3}$ & $\mathrm{H}_{2}$ & $\mathrm{H}_{1}$ & $\mathrm{~S}_{1}$ & $\mathrm{~S}_{2}$ & $\mathrm{~S}_{3}$ & $\mathrm{~S}_{4}$ & $\mathrm{~S}_{5}$ & $\mathrm{~S}_{6}$ \\
\hline NA & 0 & 0 & 0 & 0 & 0 & 0 & 0 & 0 & 0 \\
\hline $0-60$ & 1 & 0 & 1 & 1 & 0 & 0 & 1 & 0 & 0 \\
\hline $60-120$ & 0 & 0 & 1 & 1 & 0 & 0 & 0 & 0 & 1 \\
\hline $120-180$ & 0 & 1 & 1 & 0 & 0 & 1 & 0 & 0 & 1 \\
\hline $180-240$ & 0 & 1 & 0 & 0 & 1 & 1 & 0 & 0 & 0 \\
\hline $240-300$ & 1 & 1 & 0 & 0 & 1 & 0 & 0 & 1 & 0 \\
\hline $300-360$ & 1 & 0 & 0 & 0 & 0 & 0 & 1 & 1 & 0 \\
\hline NA & 1 & 1 & 1 & 0 & 0 & 0 & 0 & 0 & 0 \\
\hline
\end{tabular}
a phase with the back emf. The VSI is functioned through the fundamental switching frequency pulses to reduce losses of switching. Table 4 represents the specifications of the BLDC motor.

Table 3. Switching states of VSI

Table 4. Specification of BLDC motor

\begin{tabular}{cc}
\hline Parameter & value \\
\hline Rated Power & $200 \mathrm{~W}$ \\
Input Voltage & $48 \mathrm{~V}$ \\
Speed & $10000 \mathrm{RPM}$ \\
Stator Resistance $\left(\mathrm{R}_{\mathrm{s}}\right)$ & $0.6 \mathrm{ohms}$ \\
Stator Inductance $\left(\mathrm{L}_{\mathrm{s}}\right)$ & $0.06 \mathrm{mH}$ \\
Number of Poles $(\mathrm{P})$ & 4 \\
Friction Coefficient $(\mathrm{B})$ & $0.0682 \mathrm{e}-3$ \\
\hline
\end{tabular}

\subsection{Modelling of the BLDC drive system}

For running the motor at different speeds, the BLDC motor drive requires a speed controller for smooth controlling of the drive. The closed-loop speed controller of a BLDC motor drive is depicted in Figure 4. In a closed loop operation, at the desired time reference speed can be changed for a drive to work at desired speeds [14-15]. In the closed loop speed controller drive, the actual speed of the motor is given back to the input. By using the control systems, the speed is adjusted and brought to the required speed. The actual speed given back to the input is measured with a reference value of speed, which generates the error signals. This is fed to the PI controller, to control the speed [16-17]. The past and the present error gets nullifies by the PI controller. The speed fed to the PI controller generates a torque reference value. This reference torque is compared with actual motor torque fed from the hall sensors. The reference current is generated by the error signals produced by the reference torque and is measured by the actual torque [18-19]. This reference current and the measured current generated error signals are fed to HC controller. The gate 
pulse to a VSI switches to turn ON or OFF is produced by the hysteresis current controller. The DC link capacitor acts as the source to a voltage source converter. All the feedback to generate an error signal is detected by the hall sensor. The speed controller by the current control method yields better results [20-21].

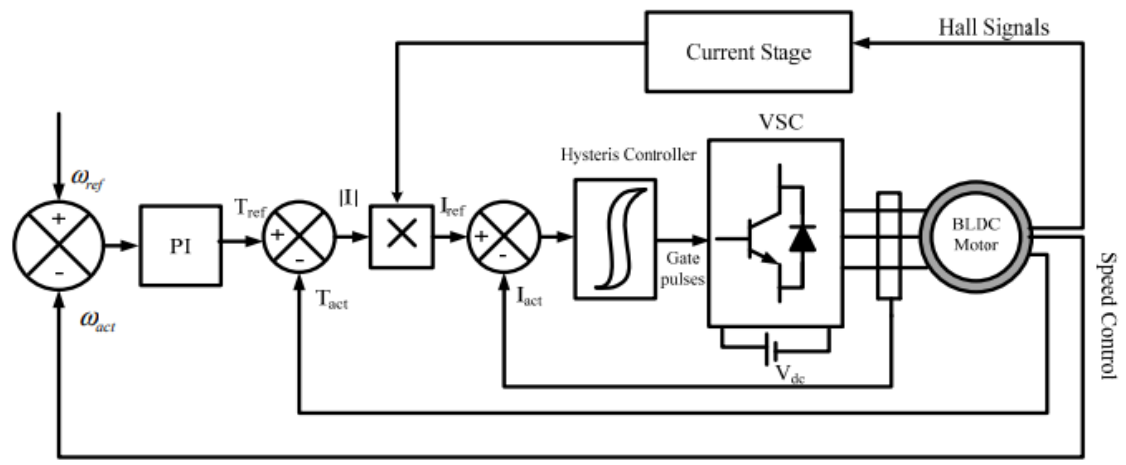

Figure 4. Schematic diagram of speed control of BLDC motor [14]

\subsection{Mathematical modelling of the BLDC motor}

Considering the cylindrical rotor and stator has three phase windings a, b, and c. The rotor is made up of permanent magnet with a uniform air gap, while the stator has three phases, which are star-connected [22-23]. The motor is not saturated as it is operated within the rated current. The dynamic equations of phase $\mathrm{a}$, phase $\mathrm{b}$, and phase $\mathrm{c}$ are:

$$
\begin{aligned}
& V_{a n}=R_{S}+L \frac{d i_{a}}{d t}+M \frac{d i_{b}}{d t}+M \frac{d i_{c}}{d t}+e_{a} \\
& V_{b n}=R_{S}+L \frac{d i_{b}}{d t}+M \frac{d i_{c}}{d t}+M \frac{d i_{a}}{d t}+e_{b} \\
& V_{c n}=R_{S}+L \frac{d i_{c}}{d t}+M \frac{d i_{a}}{d t}+M \frac{d i_{b}}{d t}+e_{c}
\end{aligned}
$$

Where $\mathrm{L}$ is a self-inductance of the armature, $\mathrm{R}$ is a resistance of the armature, $\mathrm{V}_{\mathrm{an}}, \mathrm{V}_{\mathrm{bn}}$, and $\mathrm{V}_{\mathrm{cn}}$ is the voltage of the terminals, $M$ is a mutual inductance of the armature and $i_{a}$, $i_{b}$, and $i_{c}$ is an input current of the motor. In the BLDC motor, the function of a rotor position is related to the back emf. Each phase of a back emf has $120^{\circ}$ phase angle differences [24]. Therefore, the equation for each phase is:

$$
\begin{aligned}
& e_{a}=K_{a} f_{a}(\theta) \omega_{r} \\
& e_{b}=K_{b} f_{b}\left(\theta+\frac{2 \pi}{3}\right) \omega_{r} \\
& e_{c}=K_{c} f_{c}\left(\theta-\frac{2 \pi}{3}\right) \omega_{r} \\
& {\left[\begin{array}{l}
V_{a n} \\
V_{b n} \\
V_{c n}
\end{array}\right]=\left[\begin{array}{ccc}
R_{s} & 0 & 0 \\
0 & R_{s} & 0 \\
0 & 0 & R_{s}
\end{array}\right]\left[\begin{array}{l}
i_{a} \\
i_{b} \\
i_{c}
\end{array}\right]+L_{s}\left[\begin{array}{c}
\frac{d i_{a}}{d t} \\
\frac{d i_{b}}{d t} \\
\frac{d i_{c}}{d t}
\end{array}\right]+\left[\begin{array}{l}
e_{a} \\
e_{b} \\
e_{c}
\end{array}\right]}
\end{aligned}
$$


The total torque is as follows:

$$
\begin{aligned}
& e_{a}=K_{a} \omega_{r} \\
& P_{m}=e_{a} i_{a}+e_{b} i_{b}+e_{c} i_{c} \\
& T_{e}=\frac{P_{m}}{\omega_{r m}}=\frac{\left(e_{a} i_{a}+e_{b} i_{b}+e_{c} i_{c}\right)}{\omega_{r}} \frac{P}{2}
\end{aligned}
$$

Mechanical Part

$$
\begin{aligned}
& T_{e}-T_{L}=J \frac{d \omega_{r m}}{d t}+B \omega_{r m} \\
& \frac{d \omega_{r m}}{d t}=\frac{P}{2 J}\left(T_{e}-T_{L}-\frac{2 B}{P} \omega_{r}\right)
\end{aligned}
$$

Where $T_{e}$ is an electromagnetic torque, $\mathrm{B}$ is a flux density, $\mathrm{T}_{\mathrm{L}}$ is a load torque, and $\mathrm{J}$ is the current density.

\section{RESULTS AND DISCUSSION}

The proposed solar-based current controlled BLDC mixer grinder was simulated in the MATLAB software. The solar irradiance was varied from $500 \mathrm{~W} / \mathrm{m}^{2}-1000 \mathrm{~W} / \mathrm{m}^{2}$, and the power output of a PV array is depicted in Figure 5. From Figure 5, it can be concluded that when the solar irradiance is $1000 \mathrm{~W} / \mathrm{m}^{2}$, maximum power output is obtained from a PV panel. Figure 6 displays the output voltage and power from a BB converter when the solar irradiance is $1000 \mathrm{~W} / \mathrm{m}^{2}$. From the PI controller, the speed is regulated as depicted in Figure 7. The reference speed and measured speed is summed, and the error signal is generated, which is given to a PI controller to nullify.

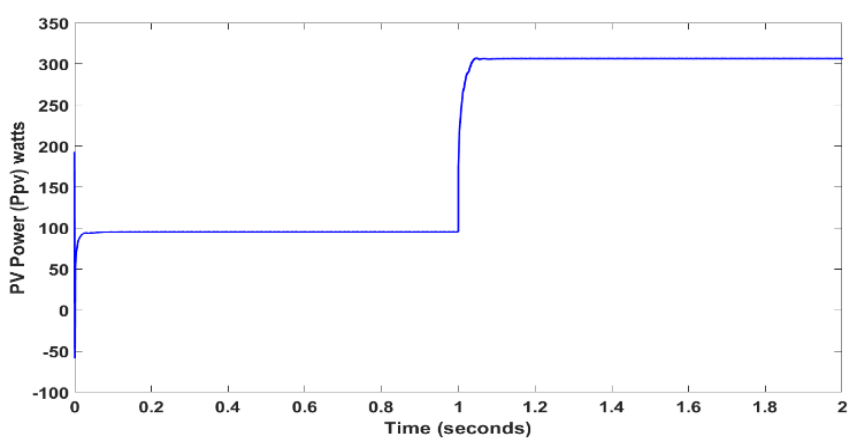

Figure 5. Output power from the PV panel

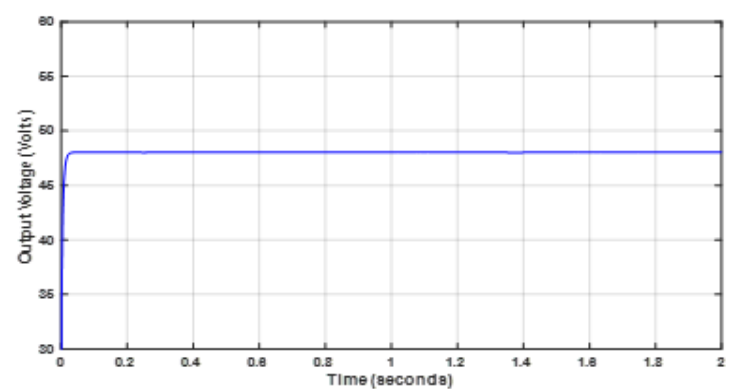

(a)

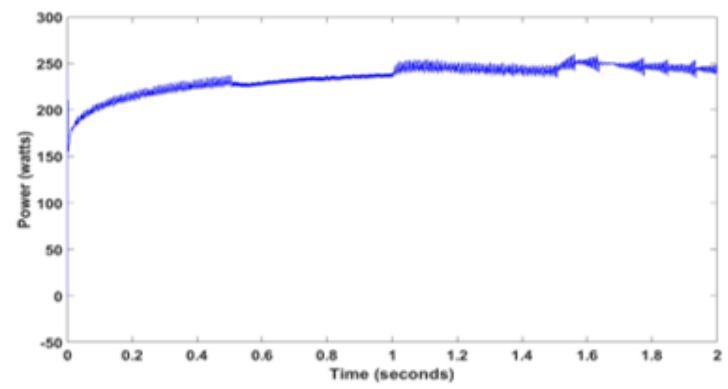

(b)

Figure 6. Voltage and power output from a buck-boost converter 


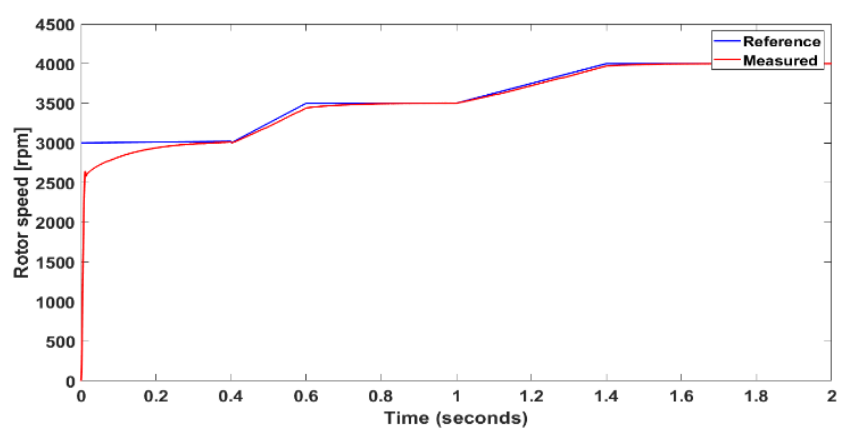

Figure 7. Reference and measured speed from the 200W BLDC motor

Figure 8 displays measured torque and phase currents of the BLDC motor. At the starting when the back emf is zero, torque is high, and as the speed increases, the torque decreases [25]. As the load increases, the motor draws more current. When the speed is increased, the current drawn decreases [26]. Philips HL 1643/04 model was used for the experimental demonstration as depicted in Figure 9. The specifications of this model are $600 \mathrm{~W}, 230 \mathrm{~V}$ AC, and speed of $18000 \mathrm{rpm}$. Flux 435 series II power quality and energy analyzer were used for taking the readings, as shown in Figure 9. Table 5 represents the comparis on of the existing mixer grinder and the simulated the proposed 48V BLDC system. If the crest factor is around 1.41, then there is an absence of distortion, and if the crest factor is above 1.8, then the amount of distortion is very high.

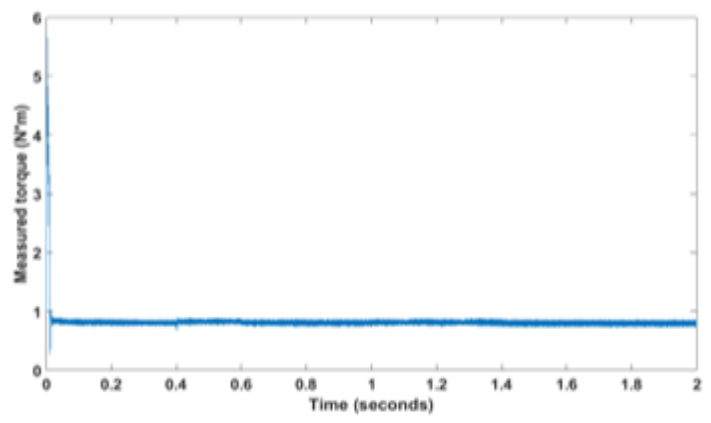

(a)

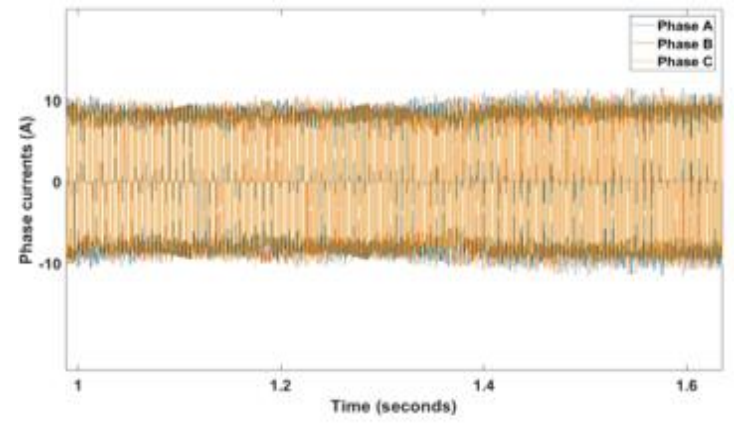

(b)

Figure 8. Measured torque and phase currents of a BLDC motor

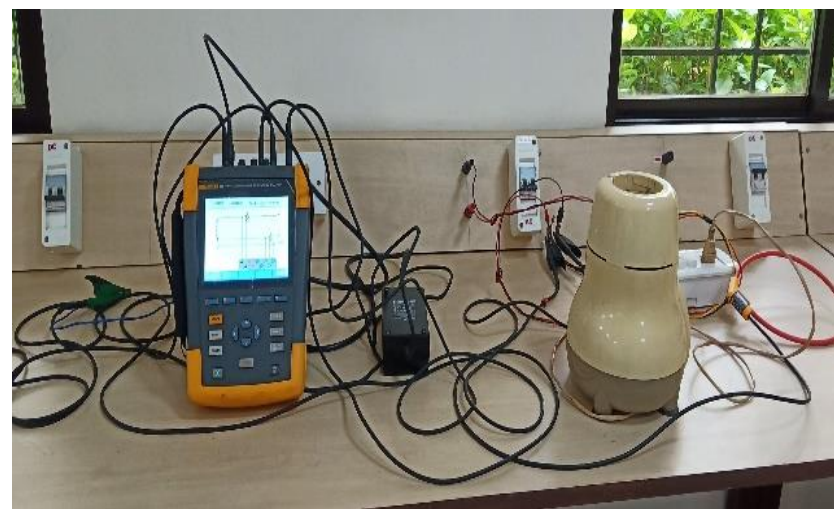

Figure 9. Experimental demonstration of existing mixer grinder 
Table 5. Comparison of the experimental existing mixer grinder and simulated proposed 48V BLDC system

\begin{tabular}{|c|c|c|c|c|}
\hline & $\begin{array}{c}\text { Experimentalexisting } \\
\text { mixer grinder } \\
(600 \mathrm{~W}) \\
\text { No load } \\
\end{array}$ & $\begin{array}{l}\text { Simulated proposed mixer } \\
\text { grinder } \\
(200 \mathrm{~W}) \\
\text { No load } \\
\end{array}$ & $\begin{array}{c}\text { Experimentalexisting } \\
\text { mixer grinder } \\
(600 \mathrm{~W}) \\
\text { With load } \\
\end{array}$ & $\begin{array}{c}\text { Simulated proposed } \\
\text { mixer grinder } \\
(200 \mathrm{~W}) \\
\text { With load } \\
\end{array}$ \\
\hline $\begin{array}{c}\text { Amount of } \\
\text { distortion (Crest } \\
\text { factor) }\end{array}$ & $\mathrm{Cf}=2.39$ & $\mathrm{Cf}=1.41$ & $\mathrm{Cf}=2.05$ & $\mathrm{Cf}=1.39$ \\
\hline $\begin{array}{l}\text { Total harmonic } \\
\text { distortion }\end{array}$ & $\begin{array}{c}\text { Voltage }=5 \% \\
\text { Current }=20.2 \%\end{array}$ & $\begin{array}{l}\text { Voltage }=3.15 \% \\
\text { Current }=3.03 \%\end{array}$ & $\begin{array}{l}\text { Voltage }=4.8 \% \\
\text { Current }=15.3 \%\end{array}$ & $\begin{array}{l}\text { Voltage }=3.35 \% \\
\text { Current }=3.45 \%\end{array}$ \\
\hline $\begin{array}{c}\text { The efficiency of } \\
\text { the system }\end{array}$ & $51.03 \%$ & $80.25 \%$ & $48.32 \%$ & $78.45 \%$ \\
\hline
\end{tabular}

\section{CONCLUSION}

As per the specification data, the proposed 48V BLDC mixer grinder using the buck-boost converter was simulated in the MATLAB/Simulink and was experimentally demonstrated along with the existing mixer grinder. The proposed closed loop current controller BLDC system was discussed. The torque, variable speed, and stator currents characteristics were also discussed. The comparative analysis of the efficiency and harmonic distortion of the experimental existing universal motor and the simulated proposed BLDC motor system was determined. Due to the absence of friction of the brushes, the efficiency of a 48V BLDC motor was higher than that of the mixer grinder operated with the universal motor. The crest factor and total harmonic distortion were higher in the exis ting mixer grinder compared with the proposed system.

\section{ACKNOWLEDGEMENT}

I like to thank my guide (Dr. R. Shivarudra Swamy) for his guidance of this research paper. I thank my HOD for his support and my college (Manipal Institute of Technology, Manipal), which provided the expertise that greatly assisted the research. I thank Mr. Jayaraj for helping in the experimental demonstration of the mixer grinder.

\section{REFERENCES}

[1] B. Singh and R. Kumar, "Simple brushless DC motor drive for solar photovoltaic array fed water pumping system," in IET Power Electronics, vol. 9, no. 7, pp. 1487-1495, June 2016.

[2] W. Chi, M. Cheng and C. Chen, "Position-sensorless method for electric braking commutation of brushless DC machines," in IET Electric Power Applications, vol. 7, no. 9, pp. 701-713, November 2013.

[3] V. Bist and B. Singh, "A unity power factor bridgeless isolated Cuk converter-fed brushless DC motor drive," in IEEE Transactions on Industrial Electronics, vol. 62, no. 7, pp.4118-4129, July 2015.

[4] S. M. Shakouhi, M. Mohamadian and E. Afjei, "Torque ripple minimisation control method for a fourphase brushless DC motor with non-ideal back-electromotive force," in IET Electric Power Applications, vol. 7, no. 5, pp. 360-368, May 2013.

[5] C. Xia, Y. Xiao, W. Chen and T. Shi, "Three effective vectors-based current control scheme for four-switch three-phase trapezoidal brushless DC motor," in IET Electric Power Applications, vol. 7, no. 7, pp. 566-574, Aug. 2013.

[6] R. Kumar and B. Singh, "BLDC motor driven solar PV array fed water pumping sy stem employ ing zeta converter," 2014 IEEE 6th India International Conference on Power Electronics (IICPE), Kurukshetra, pp. 1-6, 2014.

[7] Huang $\mathrm{C}$ and Chen H, "Design of buck type current source inverter fed brushless DC motor drive and its application to position sensorless control with square-wave current," IET Electric Power Appl., vol. 7, no 5, pp.416-426, May 2013.

[8] Xia L. "Permanent magnets BLDC motor drive and control," John Wiley \& Sons, Beijing, pp.1-281, 2012.

[9] R. Kumar and B. Singh, "Solar PV powered BLDC motor drive for water pumping using Cuk converter," in IET Electric Power Applications, vol. 11, no. 2, pp. 222-232, March 2017.

[10] Mozaffari Niapour, Sharifian, Feyzi and Danyali, "Brushless DC motor drives supplied by PV power sy stem bas ed on Z-source inverter and FL-IC MPPT controller," Energy Conversion and Management, vol. 52, no. 8-9, pp.3043-3059, Aug 2011.

[11] S. H. Hosseini, F. Nejabatkhah, S. A. K. Mozafari Niapoor and S. Danyali, "Supplying a brushless de motor by z-source PV power inverter with FL-IC MPPT," The 2010 International Conference on Green Circuits and Systems, Shanghai, pp. 485-490, 2010.

[12] M. A. Elgendy, D. J. Atkinson and B. Zahawi, "Experimental investigation of the incremental conductance maximum power point tracking algorithm at high perturbation rates," IET Renewable Power Generation, vol. 10, no. 2, pp. 133-139, Feb 2016. 
[13] M. A. Ghasemi, H. M. Foroushani and M. Parniani, "Partial shading detection and smooth maximum power point tracking of PV Arrays Under PSC," in IEEE Transactions on Power Electronics, vol. 31, no. 9, pp. 6281-6292, Sept 2016.

[14] P. Sarala, S. F. Kodad and B. Sarvesh, "Analysis of closed loop current controlled BLDC motor drive," International Conference on Electrical, Electronics, and Optimization Techniques (ICEEOT), Chennai, pp. 1464-1468, 2016.

[15] Sundareswaran K, Palani S and Vignesh Kumar V, "Development of the hybrid genetic algorithm/P\&O algorithm for MPPT in PV systems under non-uniform insolation," IET Renewable Power Generation, vol. 9, no 7, September 2015, pp. 757-765.

[16] J. S. Park and K. Lee, "Online advanced angle adjustment method for sinusoidal BLDC motors with misaligned hall sensors," in IEEE Transactions on Power Electronics, vol. 32, no. 11, pp. 8247-8253, Nov 2017.

[17] H. Li, S. Zheng and H. Ren, "Self-correction of commutation point for high-speed sensorless BLDC motor with low inductance and nonideal back EMF," in IEEE Transactions on Power Electronics, vol. 32, no. 1, pp. 642-651, Jan 2017.

[18] S. Chen, G. Liu and L. Zhu, "Sensorless control strategy of a $315 \mathrm{~kW}$ high-speed BLDC motor based on a speedindependent flux linkage function," in IEEE Transactions on Industrial Electronics, vol. 64, no. 11, pp. 8607-8617, Nov 2017.

[19] M. R. Feyzi, M. Ebadpour, S. A. K. Mozaffari Niapour, A. Feizi and R. M. Aghdam, "A new single current strategy for high-performance brushless DC motor drives," 24th Canadian Conference on Electrical and Computer Engineering(CCECE), Niagara Falls, Canada, pp.419-424, 2011.

[20] C. R. Balamurugan and K. Vijayalakshmi, "Comparative analy sis of various Z source based five level cascaded H bridge multilevel inverter," Bulletin of Electrical Engineering and Informatics, vol. 7, no. 1, pp. 1-14, 2018.

[21] R Singh, Saurabh B and Harinder Singh, "Comparative study of PWM control and PI control of Induction motor," Bulletin of Electrical Engineering and Informatics, vol. 4, no 1, pp. 53-58, 2015.

[22] Z. Q. Zhu, D. Howe and C. C. Chan, "Improved analytical model for predicting the magnetic field distribution in brushless permanent-magnet machines," in IEEE Transactions on Magnetics, vol. 38, no. 1, pp. 229-238, Jan 2002.

[23] Nayagam V Senthil and L. Premalatha, "Green energy based coupled inductor interleaved converter with MPPT technique for BLDC application," International Journal of Power Electronics and Drive Systems, vol. 9, pp. 1725-1732, 2018 .

[24] Ahmed Akram H, B. Abd El Samie and Ayman M Ali, "Comparison between fuzzy logic and PI control for the speed of BLDC motor," International Journal of Power Electronics and Drive Systems, vol. 9, no 3, pp. 1116-1123, 2018.

[25] D. S. Nayak and R. Shivarudra Swamy, "Loss and efficiency analy sis of universal motor used in mixer grinder by mathematical modelling," IEEE International Conference on Automatic Control and Intelligent Systems (I2CACIS), Shah Alam, pp. 105-110, 2018

[26] Gaing and Zwe-Lee, "A particle swarm optimization approach for optimum design of PID controller in AVR system," IEEE Transactions on Energy Conversion, vol. 19, no 2, pp.384-391, 2004.

\section{BIOGRAPHIES OF AUTHORS}

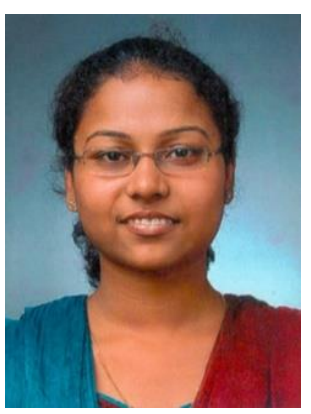

Deekshitha S Nayak, Research Scholar in the Department of Electrical and Electronics Engineering in Manipal Institute of Technology, Manipal. Completed B.E (Electrical and Electronics) degree at YIT Moodbidri in the year 2014 and M.Tech (Electronics) degree at Canara Engineering College in the year 2016. The area of interest are Renewable Energy, Power Electronics, Motor and Drives.

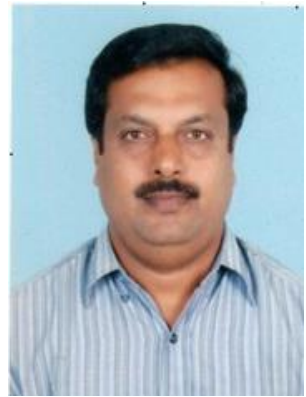

R Shivarudra Swamy, working at Manipal Institute of Technology, Manipal, in the Department of Electrical \& Electronics as an Associate Professor from last 15 Years, before worked in the Industry as an Electrical Maintenance Engineer about 3 and half years. Completed B.E (Electrical) degree at SIT Tumkur in year 1994 \& M. Tech degree at Malnad College of Engineering in the year 2002 \& completed Ph. D degree at NITK Surathkal, Karnataka in the year 2013, The area of research Interest are Distributed Generators and Energy conservation and Management. Published many papers in the National \& International Conferences \& Journals. 